\title{
PELAKSANAAN EVALUASI ASUHAN KEPERAWATAN TERHADAP PELAYANAN PERAWAT
}

\author{
Ade Sulistya Lubis/181101121 \\ adesulistyalubis@gmail.com
}

\begin{abstract}
Abstrak
Latar belakang: Evaluasi asuhan keperawatan merupakan fase akhir dari proses keperawatan. Pelayanan keperawatan merupakan salah satu faktor penentu baik buruknya mutu dan citra rumah sakit. Tujuan: dapat mengetahui bagaimana pelaksanaan evaluasi asuhan keperawatan terhadap pelayanan perawat.Metode: menggunakan metode tersearch dan analisis dari berbagai sumber seperti buku teks, buku referensi jurnal, e-book. Hasil: Hal-hal yang dievaluasikan adalah keakuratan, kelengkapan, kualitas data, teratasi atau tidaknya masalah klien, dan pencapaian tujuan serta ketepatan intervensi keperawatan. Kesimpulan: untuk meningkatkan asuhan keperawatan perlu adanya suatu penerapan sebagai pedoman kerja bagi tenaga keperawatan
\end{abstract}

\section{Kata kunci: Evaluasi, Asuhan Keperawatan, Pelayanan perawat}

Background: Evaluation of nursing care is the final phase of the nursing process. Nursing service is one of the determinants of the quality and image of a hospital. Objective: to find out how the implementation of nursing care evaluation to nurse services. Method: using search methods and analysis from various sources such as textbooks, journal reference books, e-books. Results: The things that were evaluated were accuracy, completeness, data quality, whether or not the client's problem was resolved, and the achievement of goals and accuracy of nursing interventions. Conclusion: to improve nursing care there needs to be an application as a work guideline for nursing staff

Keywords: Evaluation, Nursing Care, Nurse Services 
PENDAHULUAN

\section{LATAR BELAKANG}

Evaluasi asuhan keperawatan merupakan fase akhir dari proses keperawatan. Hal-hal yang dievaluasikan adalah keakuratan, kelengkapan, kualitas data, teratasi atau tidaknya masalah klien, dan pencapaian tujuan serta ketepatan intervensi keperawatan (Nursalam,2007)

Kriteria perawat mengevaluasi kemajuan klien terhadap tindakan keperawatan dalam pencapaian tujuan, dan merevisi data dasar dan perencanaan meliputi menyusun perencanaan evaluasi hasil dari intervensi secara komprehensif, tepat waktu dan terus menerus, menggunakan data dasar dan respon klien dalam mengukur perkembangan kearah pencapaian tujuan, memvalidasi dan menganalisis data baru dengan teman sejawat, bekerjasama dengan klien, keluarga untuk memodifikasi rencana asuhan keperawatan, mendokumentasikan hasil evaluasi dan memodifikasikan perencanaan (Nursalam,2007).

Ada dua macam evaluasi yaitu evaluasi formatif, evaluasi yang merupakan hasil observasi dan analisa perawat terhadap respon klien segera pada saat dan setelah intervensi keperawatan dilaksanakan dimana evaluasi ini dapat dilakukan secara spontan dan memberi kesan apa yan terjadi pada saat itu. Evaluasi somatif, yaitu evaluasi yang merupakan rekapitulasi dan kesimpulan dari observasi dan analisis status kesehatan klien sesuai dengan kerangka waktu yang ditetapkan pada tujuan keperawatan (Nursalam,2007).

\section{TUJUAN}

Tujuan pembandigan dari beberapa jurnal dan sumber lainnya agar dapat mengetahui bagaimana pelaksanaan evaluasi asuhan keperawatan terhadap pelayanan perawat.

\section{METODE}

Jurnal ini menggunakan metode tersearch dan analisis dari berbagai sumber seperti buku teks, buku referensi jurnal, ebook. Dari analisi berbagai sumber digunakan Untuk mengetahui bahagaimana pelaksanaan evaluasi asuhan keperawatan terhadap pelayanan perawat.

Penulisan jurnal ini dimulai pada tanggal 24 november 2019. Pengolahan jurnal dilakukan dengan metode 
membandingkan beberapa jurnal yang berhubungan dengan pelaksanaan evaluasi asuhan keperawatan terhadap pelayanan perawat.

\section{HASIL}

Tugas pokok perawat menurut KepMenPan No 94 tahun 2001 tentang Jabatan dan fungsi Perawat adalah memberikan pelayanan keperawatan berupa asuhan keperawatan atau kesehatan. Dunia keperawatan di Indonesia telah banyak mengalami kemajuan, namun pelayanan keperawatan masih belum memuaskan. Salah satu faktor yang mempengaruhi kualitas pelayanan asuhan keperawatan ini adalah ada atau tidaknya standar asuhan keperawatan. Fakta menunjukkan bahwa dari 10 dokumentasi asuhan keperawatan, dokumentasi pengkajian hanya terisi $25 \%$, dokumentasi diagnosa perawatan 50\%, dokumentasi perencanaan hanya 37,5\%, dokumentasi implementasi hanya 37,5\% dan dokumentasi evaluasi hanya $25 \%$. Sisanya tidak ada dokumentasi sama sekali.

Menurut Rasno, 1999 berdasarkan hasil penelitian pencapaian pelaksanaan standar asuhan keperawatan di tahun 1999 di RSUD Dr.H.Soewondo Kendal menunjukkan tidak lengkapnya pengisian rekam medis dan standar asuhan keperawatan hanya berkisar 50\%, sedangkan menurut Kurniawan, 2000 berdasarkan hasil penelitian secara keseluruhan pendokumentasian proses keperawatan pada pasien Hepatitis Virus Di Irna RSUP DR. Sarjito Yogyakarta mendapat skor $58 \%$ dengan kategori cukup memenuhi standar asuhan keperawatan.

Dunia keperawatan di Indonesia terus berkembang, seiring dengan meningkatnya strata pendidikan keperawatan di Indonesia, disamping akses informasi yang sangat cepat di seluruh dunia. Hal itu membawa efek pada kemajuan yang cukup berarti di keperawatan. Tenaga perawat sebagai salah satu tenaga yang mempunyai kontribusi besar bagi pelayanan kesehatan, mempunyai peranan penting untuk meningkatkan mutu pelayanan kesehatan. Dalam upaya meningkatkan mutu pelayanan kesehatan, seorang perawat harus mampu melaksanakan asuhan keperawatan sesuai standar, yaitu dari 
mulai pengkajian sampai dengan evaluasi (Jasun, 2006).

Pelayanan keperawatan diberikan akibat adanya kelemahan fisik dan mental, keterbatasan pengetahuan serta kurangnya kemauan untuk melaksanakan kegiatan hidup sehari-hari. Pelayanan keperawatan merupakan salah satu faktor penentu baik buruknya mutu dan citra rumah sakit, oleh karenanya pekerjaan perawat perlu ditingkatkan seoptimal mungkin dan untuk meningkatkan asuhan keperawatan perlu adanya suatu penerapan sebagai pedoman kerja bagi tenaga keperawatan (Ali, 2001).

Masyarakat memerlukan pelayanan keperawatan yang bermutu dan dilandasi dengan jiwa manusiawi. Keperawatan di Indonesia saat ini masih dalam suatu proses profesionalisasi, yaitu terjadinya suatu perubahan dan perkembangan karakteristik sesuai tuntutan secara global dan lokal. Untuk mewujudkannya maka perawat harus mampu memberikan asuhan keperawatan secara professional kepada klien (Nursalam, 2001).

\section{PEMBAHASAN}

Tahap evaluasi merupakan tahap terakhir dari proses keperawatan berupa perbandingan yang sistematis dan terencana dari hasil-hasil yang diamati dengan tujuan dan kriteria hasil yang dibuat pada tahap perencanaan. Evaluasi dilakukan dengan cara berkesinambungan dengan melibatkan pasien dan tenaga kesehatan lainnya. Apabila hasil menunjukkan ketercapaian tujuan dan kriteria hasil, maka pasien keluar dari siklus proses keperawatan, namun apabila sebaliknya, maka pasien masuk ke dalam siklus proses keperawatan mulai dari pengkajian ulang (Potter \& Perry, 2005).

Kegiatan evaluasi yang dilaksanakan terkait dengan hasil-hasil yang diperoleh setelah melakukan tindakan. Menurut asumsi peneliti tahap evaluasi yang baik ini juga dapat dipengaruhi oleh tingkat pendidikan responden sehingga menunjang kinerja responden dalam mererapkan asuhan keperawatan khususnya dalam menerapkan tahapan evaluasi keperawatan. 


\section{PENUTUPAN}

\section{KESIMPULAN}

Pelayanan

keperawatan

merupakan salah satu faktor penentu baik buruknya mutu dan citra rumah sakit, oleh karenanya pekerjaan perawat perlu ditingkatkan seoptimal mungkin dan untuk meningkatkan asuhan keperawatan perlu adanya suatu penerapan sebagai pedoman kerja bagi tenaga keperawatan.

\section{SARAN}

Untuk mewujudkan suatu
perubahan dan perkembangan
karakteristik sesuai tuntutan secara global
dan lokal perawat harus mampu
memberikan asuhan keperawatan secara
professional kepada klien

\section{REFERENSI}

Asmadi. 2008. Konsep Dasar Keperawatan. Jakarta : EGC

Asmuji. 2012. Manajemen Keperawatan Konsep dan Aplikasi. Jogjakarta: Ar-Ruzz Media.

Haryanto. 2007. Konsep Dasar Keperawatan dengan Pemetaan Konsep. Jakarta : Salemba medika.
Kemenkes RI. (2015). Profil Kesehatan Indonesia Tahun 2014. Jakarta..

Kozier, Barbara. (2010). Buku Ajar Fundamental Keperawatan; Konsep, Proses dan Praktik edisi 7 Volume. Jakarta: EGC.

Nursalam. (2011). Manajemen Keperawatan. Edisi 3. Salemba medika;287-94.

Rohmah, N.Integrasi proses keperawatan dalam pembelajaran klinik keperawatan one to one teaching and feed back. Vol. 1, No. 1, Desember 2010: The Indonesian Journal Of Health Science

Simamora, R. H. (2019). Menjadi Perawat yang: CIH'HUY. Surakarta: Kekata Publisher.

Simamora, Roymond H. 2010. Komunikasi dalam Keperawatan, Ed 1 hal 210. Jember: Univesity Press.

Simamora, Roymond H. Dokumentasi Proses Keperawatan, 'Ed 1 hal 144. Jember: University Press.

Simamora, Roymond H. 2008. Peran Manajer dalam Pembinaan Etika Perawat Pelakasanaan dalam Peningkatan Kualitas Pelayanan 
Asuhan Keperawatan: Jurnal

IKESMA, Ed 4, 2.

Smeltzer, Suzanne C dan Brenda G Bare. (2001). Buku Ajar Keperawatan Medikal Bedah Brunner \& Suddarth. Edisi 8. Jakarta :EGC

Suyono, Slamet. (2001). Buku Ajar Ilmu Penyakit Dalam. Edisi 3. Jilid I II. Jakarta.: Balai Penerbit FKUI

Potter, P. A \&Perry, A. G. (2005). Buku Ajar Fundamental Keperawatan.Jakarta: EGC.

Potter \& Perry. (2009). Fundamental of Nursing. 7 th Ed. St Louis Missouri: Elseiver

Perry, A. G., \& Potter, P. A. (2009). Potter and perry's fundamentals of nursing Australian version. (J. Crips \& C. Taylor, Eds.) ( $3^{\text {rd }}$ ed). Australian : mosby Elsevier Australia.

Potter, P.A.,\& Perry, G.A. (2010). Fundamental of nursing (Volume 2, 7th Ed.). ST. Louis: Mosby Year Book.

Potter, P. A., \& Perry, A. G., (2013). Fundamentals of nursing. ( $\left.8^{\text {th }} \mathrm{ed}\right)$. Elsevier. 